\title{
Whooping down Memory Lane
}

\section{Tressernes litteratur/ Litteraturens tressere}

\author{
THOMAS SCHØDT RASMUSSEN
}

Hans Meinert Sørensen

in memoriam

Tressernes litteratur: Et litteraturhistoriografisk problem

Tresserne var en voldsom brydningstid i Amerika og i den amerikanske litteratur. På lidt over ti år bevægede Amerika sig fra stilstand, kold krig, Eisenhower og debatten om romanens $d \varnothing d$ til kaos, våbenkapløb, Vietnam, modkultur og en overordentlig levende litteratur. Afstanden mellem Eisenhowers Amerika og Woodstock synes uoverstigelig, ligesom de mellemliggende kriser, bevægelser, opstande, hændelser og nybrud synes at sprænge rammerne for et enkelt årti.

Inden for ti år blev John F. Kennedy vafgt og myrdet, Lyndon B. Johnson trak krigen i Vietnam op af hatten, og Richard M. Nixon blev valgt som præsident og som den populæreste mand i USA, foran John Wayne. SNCCs sit-ins gjorde en ende på Sydstaternes apartheid, men ikke på racediskriminationen og bitterheden. Efter ikke-volden kom opstandene i Watts, Newark og overalt i USA. Black Panthers opstod og både Malcolm X og Martin Luther King blev myrdet. I 1964 blev det amerikanske tv-publikum chokeret over billederne af studenterlederen Mario Savio, der blev slået ned af betjente, mens han talte ved et officielt møde på Berkeley-men allerede fire år senere var sympatien skiftet, og politiet kunne gå bersærk på demonstranterne i Chicagos gader uden at miste befolkningens støtte. Ved årtiets afslutning kostede 
opstandene menneskeliv både ved Berkeley, Kent State og Jackson State University. A f andre større og mindre hændelser kunne man nævne Cubakrisen, feminismen, miljøbevægelsen, LSD, den fabrikerede episode i Svinebugten, modkulturen, månelandingen, den seksuelle revolution, My Lai, Woodstock, mordet på Robert Kennedy - for ikke at tale om revolutionerne inden for sceneteater, politisk teater, billedkunst, konceptkunst, film, musik og litteratur.

Også rent litterært var tresserne en periode med uoverskuelige mængder af bevægelser, revolutioner, konservative modtræk, eksperimenter- og udviklinger, der sprænger årtiets rammer. Dette er helt konkret, eftersom udviklingen i de tidlige tressere er umulige at forstå uden de sene halvtredsere, ligeså vel som mange af de bevægelser, der var undervejs i tresserne, først trådte i karakter i de tidlige halvfjerdsere. Følger man de store udviklingers kronologi, kan man tidsfæste den flossede mængde af 'tresserlitteratur' til perioden mellem 1955 og 1975. Den store diversitet og bredde $g \varnothing r$ det umuligt at beskrive tressernes litteratur som en samlet udvikling. Memory Lane er, med Robert Coovers ord, en labyrint på størrelse med selve kontinentet:

They're all whooping their hearts out as they plunge headlong, hand-inhand down memory lane-which is, itself, from sea to shining sea a marvelous and unending labyrinth 1

Tressernes litteratur oplever en revival i disse år, hvor romaner i stort tal indlemmes i Penguins Twentieth Century Classics serie og i den mere eksklusive Everyman's Library. Denne kanonisering er dog ikke entydig, eftersom den falder sammen med den politiske korrektheds gennemslag i den amerikanske litteraturhistoriografi. Tresserlitteraturen lider i den forbindelse under det beklagelige faktum, at den primært er skrevet af hvide, engelsksprogede mænd. Den politiske korrekthed fører til en ideologikritisk og minoritetspolitisk litteraturkritik, der betragter den vestlige kanon som et minoritetsundertrykkende magtmiddel. Denne totale omvurdering, hvor de sidste ti års kanon af postmoderne tresserromaner er blevet tilsidesat_til fordel for en meget vid 
kanon af identitetssøgende minoritetslitteratur, illustrerer i hvilken grad forståelsen af tresserne som litterær periode afhænger af det aktualiserende perspektiv: postmodernismens kanon henviste til en række begrebsdannelser i den franske sprogfilosofi, mens den politiske korrekthed henviser til det biografiske og det minoritetspolitiske. I begge tilfælde opstår store blindvinkler, både i stoffet og i konteksten, og der kan derfor være god grund til at medtænke kanoniseringsprocessen direkte i det litteraturhistoriske arbejde.

1.

I indledningen til Gyldendals Verdenslitteraturhistorie formulerer Hans Herte! et meget karakteristisk ståsted for halvfjerdsernes litteraturvidenskab:

Tekster er udtryk for sociale kræfter og bevægelser. Tit vil de bekræfte de raske i retten til riget, legitimere magten, eller bare en gruppes egne værdinormer. Tit er de varer. Men tit vil de også analysere og forbedre vilkårene ved at formulere modstykker og utopier. Og som bekendt er de jævnligt samtidig kunst.2

Et sådant fokus på tekster og sociale kræfter frem for litteratur, gør det næsten umuligt at skrive kvalificeret litteraturhistorie, men det er heller ikke målet med Hertels værk, som han beskriver således:

Epoke for epoke vil man se hvordan skuepladsen for det historiske liv vokser og nye folkeslag træeder ind i (litteratur)historien. Det er et stykke kulturhistorie om digtningens rolle i civilisationshistorien. ${ }^{3}$

I opposition til denne kritik, der reducerer litteraturen til et fikspunkt for en politisk eller bevidsthedssociologisk analyse, fokuserede den postmoderne kritik på formsprogets eksperimenter og på det sprogliges ironiske subversion af det tematiske og det ideologiske. Skønt begrebet om den postmoderne litteratur kan .føres helt tilbage til 1959, var det først omkring 1980, at diskussionen om det postmoderne kom til at dominere litteraturvidenskaben. Postmodernismen betød en tilbagevenden til det litte- 
rære og et tiltrængt opgør med det udvidede tekstbegreb og den socialanalytiske og bevidsthedssociologiske tekstlæsning. Omslaget var noget nær antitetisk. Hvor det udvidede tekstbegreb nedbrød forestillingen om en central kanon, etablerede den postmoderne kritik en meget snæver kanon. Hvor man i halvfjerdserne læste samfundet gennem litteraturen, hævdede man i firserne, at fiktion kun kan henvise til andre fiktioner, at sproget undergraver enhver forfatter- og tekstintention, og at selve referentialiteten skrider på grund af sprogtegnets afgrundsdybe spaltning mellem signifie og signifiant. Hvor halvfjerdserkritikken var politisk, var firserkritikken direkte anti-ideologisk. De eneste fællestræk mellem tiårenes litteraturvidenskab var et tungt fokus på teori og en generel ambivalens over for litteraturhistorien. Den snævre kanon af psykoanalytiske og marxistiske tekster blev skiftet ud med en lige så snæver kanon af fransk sprogfilosofi. Samtidig blev interessen for Historien skiftet ud med en interesse for Litteraturen. Den postmoderne tænkning afslørede halvfjerdsernes gigantiske synteser som konstruktioner og opstillede i stedet en lille kanon af enkeltværker. Uden sammenhænge, kontekster og udviklingsforløb afmonteres litteraturhistorien som projekt. Dette ses helt konkret i de seneste års amerikanske litteraturforskning, hvor de bedste værker er essaysamlinger, der søger at skabe en ramme om læsninger af få enkeltværker. Fælles for disse bøger er, at de alle behandler den samme kanon af eksperimenterende tresser- og halvfjerdserromaner og at de alle vælger en anden vinkling end den mest indlysende-den litteraturhistoriske. 4

2.

I det hele taget er der god grund til at være meget varsom med brugen af begrebet om det postmoderne i forbindelse med den amerikanske tresserlitteratur. For det første er begrebet gennemsyret af fransk filosofi, i en grad der gør det svært at stille skarpt på det særegne ved de enkelte romaner. For det andet er modsætningen mellem traditionel og postmoderne litteratur problematisk, eftersom den postmoderne kritik afviser tanken om stabile modsætninger. I stedet kunne man, med et begreb fra John Barth, 
tale om en pragmatisk opposition mellem en neorealistisk og en counterrealistisk tresserlitteratur. Begge grupper er meget heterogene og langt fra entydige, eftersom forfattere kan skifte gruppe imellem - eller endog i løbet af det enkelte værk.

Til neorealisterne hører Saul Bellow, Philip Roth, Erica Jong, Truman Capote, Ken Kesey, Richard Fari:fia, Joyce Carol Oates, Norman Mailer, John Updike, James Baldwin og John Cheever. Den neorealistiske litteratur er præget af en social, psykologisk og narrativ genkendelighed. Genkendeligheden udelukker langtfra eksperimentet eller nyskabelsen. ${ }^{5}$ Nogle forfattere skabte, med deres meget konkrete identitetssøgende eller direkte bekendende indhold, en litterær brugskunst, der afsøgte grænserne mellem selv og verden og mellem forfatter og værk. Et eksempel er Philip Roth, der har lidt den uretfærdige skæbne, at hans originale litterære modus er blevet skabelon for en stor minoritetslitteratur, der idag påkalder sig al opmærksomheden og derved marginaliserer Roth. Andre neorealister eksperimenterede med rammerne for den samtidshistoriske roman. I tråd med. tidens krav om en engageret kunst, skabte forfattere som Truman Capote, Norman Mailer og Tom Wolfe New Journalism romanen, der tager den journalistiske skildring som udgangspunkt for en romankunst, der er radikal i sin måde at skrive hen over faktiske hændelser på. Til den neorealistiske litteratur hører også den kønspolitiske bildungsroman (Erica Jong, Philip Roth), den etniske identitetsroman (Scott Momaday, Toni Morrison), den rebelske attituderoman (Richard Fari:fia, Toll $\backslash$ Robbins) og den filosofiske identitetsallegori (Robert Pirsig, Richard Bach). Disse genrer er alle nye og hører tresserne til. Alligevel har de stået i skyggen af den postmoderne litteratur, fordi deres eksperimenter ligger i indholdet og på det politiske plan, og ikke i formsproget.

Counterrealisme kan både forståes som anti-realisme og realisme på vrangen. Counterrealisterne er den blandede gruppe af eksperimenterende forfattere, der gerne kategoriseres som postmodernisterne: Thomas Pynchon, Donald Barthelme, John Barth, Robert Coover, William S. Burroughs, William Gaddis, Kurt Vonnegut, Rudolph Wurlitzer, Richard Brautigan, William Gass, Jo- 
seph Heller og Ishmael Reed. Den eksperimenterende tresserlitteratur tog sin begyndelse i midten af halvtredserne, med William S. Burroughs' og William Gaddis' romaner. Burroughs var måske den første til at se de traditionelle sproglige og narrative strukturer som farlige blindgyder-ik ke blot for litteraturen, men for menneskeheden. Hans radikale synspunkter, f.eks. at sproget er en ondsindet virus fra det ydre rum, førte til nogle lige så radikale litterære eksperimenter, rettet mod sprogets kontrolstrukturer. Det mest kendte af disse eksperimenter er cut-up teknikken, hvor Burroughs klippede i manuskriptark og lod tilfældet sætte romanerne sammen. Helt anderledes er Gaddis' hovedværk, den enorme The Recognitions (1955), der undersøger alle former for forfalskning, i en dyster, ironisk og meget kompleks romankonstruktion. Trods den dybe forskel mellem ironien og hyperkompleksiteten hos Gaddis og den ekstreme paranoia og humor hos Burroughs, væver trådene fra de to sig gennem tressernes eksperimenterende litteratur.

I første omgang blev stilen døbt 'sort humor' på grund af den drillende eller pessimistiske afstandstagen til den traditionelle '!Oman eller short-story. Black Humor var en bred samlebetegnelse for en række forskellige litterære bestræbelser, der blot havde det tilfælles, at de vendte sig bort fra den traditionelle litterære stil. Som eksempler på black humor, kunne man fremhæve John Hawkes mareridtsagtige og næsten formløse romaner, der foretager surrealistiske dyk i efterkrigstidens voldelige bevidsthed og Bruce Jay Friedmans relativt simple, men grumt ironiske romaner. Mest kendt er Joseph Hellers Catch-22 fra 1961. En egentlig postmoderne litteratur, der ikke skuffer læserens forventning om at blive taget ved næsen, finder man i Donald Barthelmes parodiske noveller; der kombinerer politisk samtidsanalyse med en meget raffineret leg med fiktionens rammer og med en dyb tristhed - en af hans bøger hedder ligefrem Sadness. Et andet eksempel er John Barths metanoveller. Barth skriver med en ekstrem sproglig selvreferentialitet, der gør novellerne i Lost in the Funhouse til pinagtige $\varnothing v e l s e r$ i litterær fremmedgørelse f.eks. i novellen "Title", der slutter på følgende måde: 
Oh God comma I abhor self-consciousness. I despise what we have come to; I loathe our loathesome loathing, our place our time our situation, our loathesoi:ne art, this ditto necessary story. The blank of our lives. It's about over. Let the denouement be soon and unexpected, painless if possible, quick at least, above all soon. Now now! How in the world will it ever6

Hvor Barth udforsker mulighederne i et entropisk og udmattet formsprog, går Robert Coover den modsatte vej. I flere af novellerne i Pricksongs \& Descants (1969) erotiserer Coover det narrative begær og skriver sig frem gennem fragmenter, der opløser narrationen i mulige forløb og forestillinger. Richard Brautigans Trout Fishing in America (1967) omsætter beatgenerationens eksistentialistiske og lav-fiktive litteratur og indsætter rastløsheden, opbruddet og den pastorale drøm i et radikalt formregister. Brautigan har stået uden for den postmoderne kanon, fordi det ikke er en postmoderne ironi, der driver romanens sproglige og narrative kaleidoskopi, men netop melankolien, naiviteten og den utopiske forening af skønhed og forfald gør Trout Fishing in America til en·af de største tresserromaner.

Ideen om det ultimative plot styrer en del af den counterrealistiske litteratur, således ser man forskellige billeder af meget dyb kontrol hos Kurt Vonnegut, der i The Sirens af Titan (1959) beskriver alle menneskehedens store bygningsværker som beskeder sendt fra den fjerne planet Tra_lfamadore til en nødstedt Tralfamadoriansk rumrejsende, der sidder på Titan og venter på en lille reservedel til sit rumskib. Betydningen af det enkelte menneskes liv, ret og ansvar forsvinder fuldstændigt, når menneskehedens samlede opgave har været at fungere som opslagstavle for ligegyldige beskeder fra Tralfamadore til Titan. En række andre, om end mindre radikale billeder af den dybe kontrol, der fratager individet dets menneskelighed, finder man hos William S. Burroughs, Norman Mailer, Joseph Heller, Thomas Pynchon og i Ken Keseys One Flew Over the Cuckoo's Nest (1962), hvor fortælleren Chief Bromden mistænker den store sygeplejerske for at kunne styre patienternes indre liv og tanker fra sit glasbur.

Disse tematiske genkomster forvaltes meget forskelligt hos de forskellige forfattere. Hvor Cuckoo's Nest og f.eks. Norman Mai- 
lers An American Dream (1965) er temmelig traditionelle romanformer, står Joseph Heller på kanten til den postmoderne roman med Catch-22, der er eksperimenterende i sit anslag, men mod slutningen tipper over i en nærved modstandsløs sentimentalitet. Thomas Pynchon, der sædvanli $\mathrm{g}_{\mathrm{v}}$ is fremhæves som den ultimative postmoderne forfatter, viser hvordan paranoiaen er et udtryk for subjektets internalisering af kontrollen, en perverteret udgave af den $\mathrm{d}_{\mathrm{y} \text { n }}$ amiske holisme, som hans romaner tenderer mod. Burroughs og Pynchon kommer derved til at.stå i direkte modsætning til forfattere som Vladimir Nabokov og John Barth, der bruger labyrinten, konspirationen og $\mathrm{h}_{\mathrm{y}}$ erstrukturen som litterære virkemidler.

I mange tilfælde er der slet ikke grund til at skelne mellem en neorealistisk og counterrealistisk litteratur, eftersom de fleste forfattere placerer sig i et bredt mellemfelt, hvor tressernes mange brydninger på den ene eller den anden måde afsætter spor i værkernes stil, tematik, metaforik eller politik. Ligeledes gælder det, at flere forfattere kan rubriceres i begge grupper alt efter hvilke af deres værker man læser, eller hvilken vinkel man lægger i læsningen af det enkelte værk. Et eksempel er Truman Capotes In Cold Blood (1966), der på en gang er en relativt traditionel roman og et eksperimenterende stykke New Journalism, eller Donald Barthelmes noveller, der både er ironiske og subversivt undergravende postmoderne perler og skarpe politiske samtidsanalyser. Problemet er, at også begrebet counterrealisme identificerer opgøret med realismen som det mest centrale ved den eksperimenterende litteratur. Begrebet er en æstetisk betinget kategori, der beskriver den litterære modus, men til gengæld skygger for litteraturens tematiske og politiske aspekter.

Et muligt kompromis mellem den politiske og den formfikserede reduktionisme, findes i den tidligste samlede fremstilling af den amerikanske tresserlitteratur.

3.

I 1971 udkom Tony Tanners bog City af Words. A Study of American Fiction in the Mid-Twentieth Century, der stadig regnes som et hovedværk.7 City of Words opstiller den kanon, der formodentlig 
vil blive stående. Tanner lægger en naturlig hovedvægt på den eksperimenterende litteratur og bruger hele kapitler på James Purdy, William Burroughs, Ralph Ellison, Thomas Pynchon, Kurt Vonnegut, John Hawkes og John Barth, mens .Walker Percy, Sylvia Plath, Susan Sontag, William Gass, William Gaddis, Donald Barthelme og Richard Brautigan behandles i mindre afsnit. Af den mere traditionelle litteratur behandles John Updike, Bernard Malamud, Norman Mailer og Ken Kesey i hele kapitler, mens Saul Bellow, Joseph Heller, Philip Roth og Frank Conroy deler to kapitler. Disse forfatterskaber og den indbyrdes vægtning går stort set igen i alle litteraturhistorier op til den seneste.

Tanners metode er lighedssøgende, uden at være syntetiserende. Han fokuserer på forholdet mellem enkeltværket og det litterære felt og opnår derved at fremlæse en række genkommende tematikker. Disse selvgenererende mønstre viser sammenhænge på tværs af forfatterskabs- og værkgennemgange. Et gennemgående tema er kravet om absolut frihed og frygten for udefrakommende kontrol, som ytrer sig på mange forskellige måder i periodens amerikanske litteratur. Frygten fører til modstand mod ydre såvel som indre organisering, herunder sprogets, stilens og narrationens strukturer, og dette fører igen til en række eksperimenter, hvor forfatterne søger at vriste sig fri af litterære konventioner og finde en stærkt individuel stil. Men skal man skrive sig bort fra kontrollens og Magtens Skylla, så er der altid faren for at falde i formløshedens Karybdis. Tanner bruger dette eksempel i introduktionen og viser, hvordan formløsheden optræder som fare ved friheden i så forskellige romaner som Saul Bellows The Adventures af Augie March, Ralph Ellisons Invisible Man, William S Burroughs' Naked Lunch, Norman Mailers An American Dream og James Purdys Cabot Wright Begins. ${ }^{8}$ Listen kan uden problemer fortsættes - og formløsheden kan både manifestere sig i værkernes plot, stil, sprog eller indhold. Det centrale er, at Tanner betragter den litterære modus som en funktion af tematikken. Han læser formen som indhold og undersøger genkommende strukturer på begge niveauer. Herved undgår han at bygge sit argument op omkring en skelnen mellem postmoderne og traditionel litteratur, sådan som så mange har gjort det efter 
ham, og det bliver herved muligt at iagttage sammenhænge i det litterære felt, som siden er blevet fortrængte. Det er evnen til at se ligheder mellem forfattere som Mailer, Malamud og Roth på den ene side og Barth, Gass og Burroughs på den anden side, der gør at Tanners bog både har kunnet stå sig gennem halvfjerdsernes freudo-marxistiske litterære socialanalytik og firsernes postmodernismediskussion.

Når City of Words trods dette ikke er den endelige litteraturhistorie for de amerikanske tressere, skyldes det først og fremmest Tanners tunge fokus på romaner, fiction, frem for litteratur. Hvor . velkomment dette end må være for det store flertal af poesiforskrækkede læsere, fører det til en generel skævhed. Umiddelbart mest iøjnefaldende er Tanners næsten totale forbigåelse af den amerikanske eksistentialisme: beat-litteraturen. Bortset fra William Gaddis, der stadig venter på sit gennembrud og William S. Burroughs, der med sin vilde eksperimenteren snarere var tekstproducent end romanforfatter, talte beat-generationen flest digtere, nemlig Allen Ginsberg, Lawrence Ferlinghetti, Gary Snyder, Peter Orlovsk $\mathrm{y}_{\mathrm{y}}$ Gregory Corso, for $\mathrm{f} 4<\mathrm{e}$ at glemme Jack Kerouac og Richard Brautigan, der begge kendes bedst for deres romaner. Beat-litteraturen opstod i en lille kreds, der først og fremmest skrev for og om hinanden. Nyskabelsen kom først som en attitude, en blanding af eksistentialistisk fremmedgørelse, bohemeromantik, $d_{\mathrm{y}}$ kelse af øjeblikkets intensitet og inspiration fra visionær, ikke-vestlig tænkning. Et af de væsentligste træk ved beat-generationen var dens fokus på livskunst frem for værkkunst. Dette ytrer sig på mange forskellige måder. Beatforfatterne var drop-outs ti år før hippierne. De vendte ryggen mod halvtredsernes ekstreme konformitet. Flere af dem var homoseksuelle, nogle var på kant med loven, de eksperimenterede med stoffer og lod sig inspirere af negermusik. Og vigtigst af alt omsatte de $\mathrm{udb}_{\mathrm{r} \text { y }}$ derattituden i det litterære formsprog og skrev i en bred gråzone mellem selvbiografi og poesi. Forfatterne optræder i hinandens værker. Der er en tydelig inspiration fra jazz-musikken, fra soloens improvisation og situationisme. Mange af Ginsbergs, Ferlinghettis, Snyders og Corsos digte er skrevet til oplæsning: til stemmens intensitet og rummets stemning. Beat- 
litteraturen er viklet ind i myten om den spontane poesi. Kerouac hævdede at han skrev On the Road på tre uger. I virkeligheden arbejdede han på romanen i flere år, meri. myten om den spontane prosa - om benzedrinrusen og den lange rulle af sammenklistrede ark - passer bedre med romanens rastløse intensitet.

Den rent litterære værdi af Jack Kerouacs romaner kan diskuteres, men Tanners fravalg af beatlitteraturen medfører en blindvinkel i forhold til den situationistiske litteratur. Og Tanners fokus på romaner fører til en endnu mere fundamental skævhed i forhold til tressernes litteratur.

Tresserne var en periode, hvor der i høj grad blev eksperimenteret med de litterære former, både i den højlitterære kunst og i den traditionelt set mindre fine litteratu:r: rockl $_{\mathrm{y}}$ ikken, manifest- litteraturen og tressernes nye genre the New Journalism. Tanner beskæftiger sig alene med kanoniserbare romaner, hvorved alle forsøg på at skabe en kunst, der ikke begrænser sig til et enkelt medie, henligger i en stor blindvinkel. Konsekvensen af dette er, at litteraturen kommer til at stå som et aflukket system, afskåret fra periodens øvrige strømninger.

Rocken behandles ofte som en historie for sig, men der er flere aspekter af tresserrocken, der har så stor betydning, at de ikke bør forbigåes i en litteraturhistorisk kontekst. For det første begyndte teksterne at få en betydning, der rakte langt ud over "I wish they all could be California giiiiirls". Musikken blev poli. tisk, ikke blot gennem protestsangene, men i langt højere grad som centralt element i ungdomsoprørets mentale infrastruktur. Hvor beat-generationen skrev digte, spillede tressergenerationen på guitar. Sgt. Pepper's Lonely Hearts Club Band fra 1967 blev et af de første albums med optrykte tekster, men det sorte og det hvide marked flød allerede med becifringer, real-books og sangtekster, så enhver kunne bruge musikken, i stedet for at være en passiv lytter. Musikken udviklede sig lige så eksplosivt som skønlitteraturen. Utallige grupper eksperimenterede med at ombryde den traditionelle melodistyrede sang, hvor forsangeren bæres oppe af instrumenter og backingvocals gennem tre ligegyldige vers og et omkvæd, der gentages et par gange til sidst. Disse eksperimenter er lige så radikale, som dem man finder i lit- 
teraturen og det kan derfor undre, at der er så stor forskel i opfattelsen af de to kunstneriske processer: den eksperimenterende roman regnes for at være intellektuel, elitær og subversiv i forhold til ethvert forsøg på kontekstualisering - et rent produkt fra elfenbenstårnet - mens den eksperimenterende rockmusik hører til livekoncerten, med omdrejningspunkter i soloen, samspillet og udvekslingen mellem musikere og publikum. Den eksperimenterende rock voksede frem på gaderne i Haight-Ashbury, på live-scenen, i nuet. I sine liner notes til albummet John Lennon. Live in New York City skriver Yoko Ono følgende om en koncert $\mathrm{i}$ 1972:

Vores koncertmateriale var hovedsageligt baseret på det album vi udgav det forår, Sametime in New York City, som var vores politiske erklæring i sange a la Bertholt Brecht. Koncerten var fyldt med kærlighed til broderskab og søsterskab. Vi uddelte tambouriner til publikum i overensstemmelse med vores slogan "I er Plastic Ono Band." Alle deltog på scenen til sidst da vi sang "Give Peace a Chance". Folk kunne ikke beherske sig og marcherede ned ad Fifth Avenue efter koncerten, mens de sang "Give Peace a Chance". Denne koncert var vores forsøg ud i græsrodspolitikken. Den var indbegrebet af det John og jeg troede kraftigt på - "Rock for Fred og Oplysning".

Rockkoncerterne forenede protestsangens og fællesskabets politik med ekstasens politik i det ultimative helhedskunstværk. Den aktive helhed af musik, politik, fællesskab, lyrik, psykedelisk lys, bevidsthedsudvidende stoffer, der tilsammen stræber efter at samle publikum som en ekstatisk krop. På denne måde er der ingen konflikt mellem fællessangens aktive medskaben, dens her-og-nu musikalitet, den stærkt eksperimenterende rock og epokens store musikalske begivenheder.

Ambitionen om at skabe grænse- og genreoverskridende po. litiske helhedskunstværker går igen i manifestlitt_eraturen, som udviklede sig fra politiske programerklæringer ${ }^{9}$ til at spille en rolle i tressernes uhyre raffinerede politiske teater. Sentressernes manifestlitteratur, som vi senere skal vende tilbage til, søgte at spille samme rolle som musikken, ved helt eksplicit at skrive sig ind i protestens, fællesskabets og ekstasens politik. Samspillet 
mellem happening, politik og manifest er en kunstnerisk ramme, der bryder de traditionelle genrer og som derfor også bliver et litterært anliggende. Det samme gælder for musikken, skønt de konkrete litterære frembringelser isoleret set ikke kvalificerer som stor litteratur. Uden at ville annektere rock og happenings fra musikvidenskaben og kunsthistorien, kan det lidt bredere fokus på periodens kunstneriske mål og ambitioner være med til at åbne for vigtige perspektiver på tressernes litteratur og litterære udvikling. Udfordringen for den litteraturhistoriske skildring er at balancere mellem tværæstetikken og bevidsthedshistorien på den ene side og den rene litterære elitisme på den anden side. Det centrale i en litteraturhistorie må til enhver tid være den kanoniske litteratur, mens undersøgelser i kontekstens materielle litterære basis er nødvendige dels for at afgøre kanoniseringens principper og dels for at nå frem mod en læsning af enkeltværket, der ikke alene baserer sig på det æstetiske og det formmæssige.

Obsceneties were shouted. There were statements that wives, mothers, and daughters of the officers at that moment were ingaging in a variety of sexual relations with black men in dormitory rooms or at home.10

\author{
All this I swallow and it \\ tastes good.. I like \\ it well, and it \\ becomes mine, \\ I am the man .... .I \\ suffered.... . was \\ there.11
}

\title{
Litteraturens tressere: Dansen om Pentagon
}

Gennemgangen af tiårets litteraturhistorie afslører et litteraturhistoriografisk dilemma. På den ene side er det klart, at periodens overflod af vigtige hændelser og værker udelukker en lineær udviklingshistorie. Enhver konstruktion i dette felt skjuler 
mindst lige så meget som den viser. De vigtige sociale og politiske omvæltninger manifesterer sig tydeligt i litteraturen, men den ideologikritiske læser bliver trukket rundt ved næsen af teksternes uhyre raffinerede formeksperimenter. Omvendt betyder postmodernismens forkastelse af konteksten, at det bliver umuligt at vurdere værkernes tematik som funktion af andet end formsproget. Nixons optræden som monster i Barthelmes, Coovers og Pynchons tekster bliver gådefuld.

Man fristes til at sige, at dagens litteraturhistorieskrivning må være en syntese af halvfjerdsernes udvidede tekstbegreb og firsernes antitetiske litterære elitisme. Den kanoniske litteratur må stå i centrum, men samtidig må dẹt litterære værk forståes som en helhed af form, indhold og en tredie part, som i mangel af bedre kan kaldes politik eller kontekst. Informationstætheden på de tre niveauer afgør værkets kanoniske status. Det litteraturhistoriske arbejde med den kanoniske litteratur må fokusere på genkommende $\mathrm{fi}_{\mathrm{g} \text { u r }}$ er $\mathrm{i}$ et kontinuert spektrum mellem konteksten og den højlitterære kunst. Kun ved at fastholde et konstant sideblik på bevægelserne i den litterære og kulturelle kontekst, er det muligt at undersøge hvordan signifikante strukturer i feltet udpeger holdningsmæssige valoriseringer i primærteksterne. Dette litteratursyn udpeger en noget større kanon end postmodernismen, uden at radbrække kanon med et udvidet tekstbegreb eller med dagens politiske korrekthed.

1.

Det overordnede problem i arbejdet med tressernes litteratur er næppe at der ikke er nogen forbindelse mellem sprog og verden, mellem værk og kontekst eller mellem form og indhold. Problemet er snarere, at der er flere forbindelser end man kan gøre sig håb om at overskue. Der findes ikke et enkelt bindeled mellem periodens mange sociale, kulturelle og litterære udtryk. Til gengæld findes der en uoverskuelig mængde af fællestræk - opgøret mod et stivnet system, trangen til selvrealisering, kravet om politisk engagement, en kiastisk $\mathrm{fi}_{\mathrm{g} \text { u } \mathrm{r}}$ af idealisme og melankoli, paranoia, eksperimenteren - både i stil og tanke, og i feltet mellem stil og tanke. Skal man pege på et eneste bindeled, skulle det 
måske netop være viljen til at se alt under et - troen på at der findes glidende overgange mellem det politiske, det litterære, det personlige, det man gør, det man spiser, den man er.

Arbejdet med og refleksionen over kanonprocessen kan være et redskab til at navigere i det litteraturhistoriske felt. Kun ved grundige beskrivelser af de måder hvorpå det historiske skriver sig ind i og ud af det litterære, kan man redigere i det litteraturhistoriske felt. Dette kan f.eks. ske ved at unders $\varnothing g e$ flere forskellige skildringer af en af tressernes karismatiske begivenheder. Myten om tressernes ungdomsoprør er spundet op omkring en række steder og begivenheder. U d over Woodstock kunne man nævne Altamont Pop, der også fandt sted i 1969, demokraternes partikonvent i 1968, demonstrationerne for The Free Speech Movement i 1964 frem til kampene om The Peoples' Park i 1969, nedskydningen af 13 studerende på Kent State University i 1970, the summer of love i Haight Ashbury i 1967 osv. osv. En af disse epi-" soder, der var med til at skabe tressernes ungdomsoprør og som spandt sig ind i periodens litteratur, var marchen mod Pentagon i oktober 1967.

2.

Marchen mod Pentagon blev planlagt i sommeren 1967 af MOBE, The National Mobilization to End the War in Vietnam, der samlede en lang række af de aktive venstrefløjsgrupper, studenterorganisationer og freds- og protestgrupper. Som repræsentant for modkulturen deltog Jerry Rubin. Rubin organiserede den første Vietnam Teach-In og den første Human Be-In, der samlede hippierne fra Haight-Ashbury og de radikale studerende fra Berkeley. Og han havde allerede gjort sig bemærket med sin symbolske krigsførelse mod det amerikanske system. Da han første gang blev afhørt af The House Un-American Activities Committee, mødte han op forklædt som soldat fra den amerikanske uafhængighedskrig, og forsøgte at vende afhøringerne til et absurd teaterstykke. Senere var han med til at stifte The Youth International Party, sammen med Abbie Hoffman. Yippierne var hverken et parti eller en protestorganisation, men en blanding af politik og modkultur. Revolutionær marxisme i traditionen fra 
Groucho, Chico, Harpo og Karl. I Do It! Scenarios of the Revolution, beskriver Rubin yippien som:

Det marxistiske syrehovede. Den psykedeliske bolsjevik. Han følte sig ikke hjemme i SDS, og han var hverken en flower-p<j>wer hippie eller en universitetsintellektuel. En skæv politikus. En blanding af New Left og hippie, der var noget ganske andet.

En gadekæmpende freak, en dropout, som bærer en pistol ved hoften. Så grim, at middelklassesamfundet er bange for hans udseende.

En langhåret, skægget, behåret, skør motherfucker hvis liv er teater, og som hvert øjeblik skaber det nye samfund mens han ødelægger det gamle.

Virkeligheden var der. Der var behov for en myte for at få energien til at samle sig.

Yippier smedede den myte.12

Flertallet af organisationerne under MOBE ønskede at bruge marchen mod Pentagon til at vise Amerika, at det ikke kun var hippier og drop-outs, der var imod krigen i Vietnam. Yippierne $ø$ nskede derimod at rette et symbolsk slag mod totalitærstatens allerhelligste. De ville overbyde protesten og den civile lydighedsnægtelse og skabe modmyter. I tiden op til marchen arbejdede Jerry Rubin og Abbie Hoffman på at sprede rygter og manipulere med medierne, for at iscenesætte marchen og skabe en myte, der kunne skabe forventninger, trække folk til og konkurrere med den officielle sandhed efterlods Yippierne truede med at bringe Vietnamkrigen hjem - at defoliere kirsebærtræerne i Washington, at farve Potomac floden lilla og at angribe alle regeringsbygninger i Washington D.C. Da politif:!t sagde, at de var parate til at bruge clen kraftige tåregas (mace) mod demonstranterne, svarede yippierne, at de ville bruge lace mod vagterne. Lace blev præsenteret ved en pressekonference som et narkotisk stof, der trænger gennem huden og frisætter kønsdriften, så vagterne ville smide uniformerne og kaste sig ud i et orgie med demonstranterne. Endelig proklamerede yippierne, at den kollektive trance omkring forsvarshovedkvarteret ville få verdens største kontorkompleks til at levitere og svæve 100 meter over jorden, hvor alle de onde dæmoner ville $d_{r y}$ sse ud. Denne dif- 
fuse myte om djævleuddrivelse, samfundsomstyrtelse og orgiastisk løssluppenhed blev til virkelighed i medierne allerede inden den blev udspillet under selve marchen.

Demonstrationen fandt sted lørdag d. 21. oktober, 1967, og samlede henved 100.000 mennesker til taler ved The Lincoln Memorial. Cirka 35.000 marcherede de fà kilometer til Pentagon. Størstedelen sivede i løbet af dagen, efter de sidste taler. Herefter fulgte en nat og en dag med happenings og sammenstød, inden militærpolitiet skovlede de sidste demonstranter sammen, natten til mandag.

Hvad der egentlig skete foran Pentagon, er det svært at få overblik over. Demonstranterne talte til soldaterne, sang, røg og udførte eksorcistiske ritualer. Viet Kong flaget vajede og murene blev bemalede med slogans. Flere tusinde mennesker - heriblandt Rubin og Hoffman, men også Norman Mailer, Noam Chomsky og David Dellinger - blev arresteret og endnu flere blev slået ned af soldaterne. Abbie Hoffman hævder i sin selvbiografi, at Pentagon faktisk løftede sig over jorden. Under alle omstændigheder lykkedes det at udnytte Pentagon som scene for et slagkraftigt og subversivt politisk teater:

Helt bortset fra metafysikken, så blev synet af planetens mest berømte krigsskabende symbol under belejring af tusindvis af dets borgere øjeblikkeligt transmitteret kloden rundt. Det behøvede ingen oversætter, ingen hokus-pokus. 13

\section{3.}

En helt anden poetik end Rubin og Hoffmans findes i Norman Mailers Pulitzerbelønnede dokudramatiske-New-Journalismfaction roman The Armies af the Night. Op gennem tresserne halsede Mailer afsted og skrev en imponerende mængde bøger, i et forsøg på at fange tidsånden. I årtiets sidste årudkom, foruden Armies af the Night (1968), romanen Why are We In Vietnam (1967), der benytter beskrivelsen af en jagtudflugt i Alaska som ramme om en allegorisk skildring af den voldelige amerikanske sjæl, der får U S A til at føre krig på den anden side af kloden; Miami and the Siege af Chicago (1968), der handler om årets to partikonventer - 
republikanernes konvent i Miami, hvor Nixon blev nomineret og demokraternes konvent i Chicago, hvor Hubert Humphrey blev nomineret, mens kampene bølgede mellem politi og unge i Chicagos gader; Of a Fire an the Maan (1969), der handler om månelandingen og beskriver NASA som model for en fremtidig amerikansk totalitærstat, bygget på WASP idealer. Fælles for bøgerne er det, at de bruger $f_{r y}$ gten for en spirende totalitarisme som drivkraft i et megalomant forsøg på at løfte en beskrivende og analyserende samtidskritik til en post-romanesk og post-historisk litteratur. Disse overvejelser er meget eksplicitte i The Annies af the Night, der er delt i to bøger med titlerne "History as a Novel" og "The Novel as Histo ${ }_{\text {r }}$ ".

Historieskrivningen i den første del sker gennem en autobiografisk skildring af Mailers egne oplevelser i dagene omkring demonstrationen. Mailer optræder både som vidne, forfatter, historiker, journalist, aktivist og som fortæller. Forfatteren og historikeren Norman Mailer skaber fortælleren Mailer, der beskriver mennesket og aktivisten Mailer. De mange Mailere vokser og sluger hele marchen. De faktiske hændelser, protesten mod krigen, myndighedernes svar, men også selve krigen, systemet, modbevægelserne og hele det splittede Amerika sluges og bliver til indre bevægelser og positioner i Mailer. Ved at internalisere marchen og sammenstødet mellem de fjerneste poler i Amerika, og gøre konflikten til et autobiografisk anliggende, søger Mailer at fastholde og analysere den fundamentale skizofreni i det amerikanske. Det autobiografiske bliver en samfundskritik. Samtidig radikaliserer Mailer spørgsmålet om forfatterens rolle, der i forvejen er centralt i New Journalism.

Kampråbet for the New Journalism var, at hverken den eksisterende journalistik, historieskrivning eller litteratur var i stand til at gribe kompleksiteten i samfundet, som det havde udviklet sig. Tom Wolfe, Norman Mailer, Truman Capote med flere hævdede, at journalistikken og historieskrivningen var nået til en grænse, hvor den var nødt til at vedkende sig sin fiktionalitet for at nå videre, samtidig med at den traditionelle romankunst var udtømt som ramme om samtidsanalyse og kritik. Udfordringen for the New Journalism var altså at finde en ramme, der var bred 
nok til at kunne fange virkeligheden i spændingsfeltet mellem det historiske og det litterære. Denne ramme viser sig ofte - og i ekstrem grad hos Mailer - at være forfatteren selv. ${ }^{14}$ Forfatteren er på en gang organisator, bindeled og rigtighedsgarant.

Disse overvejelser føres videre i den anden bog i Armies of the - Night, der er helt forskellig fra den første. Første bog, "History as a Nover, er en autobiografisk roman, der hævder at være historieskrivningen. Anden bog, "The Novel as History", modsvarer dette ved at efterligne en traditionelhistorieskrivning, uden dog at give slip på romanens virkemidler. Mailer giver slip på sin position som tekstens eneste akse og øje, og henviser til avisartikler, øjenvidneskildringer og andet materiale. Forfatteren Mailer trækker fortælleren Mailer i baggrunden og tildeler aktivisten :tvt:ailer en mindre rolle i begivenhederne. Alligevel fortsætter forfatteren Mailer med at indskrive fiktive dialoger, der italesætter de bølgende bevægelser mellem soldater og demonstranter. Fiktionen bruges til at overskride det faktiske i fakticitetens navn.

Målet med denne brede gråzone mellem fiktion og fakticitet er klart politisk. Ved at arbejde i det tilsyneladende paradoksale felt mellem internalisering og analyse, at samle og at adskille, formår Mailer at uddestillere og fastholde de træk han ønsker at kritisere, samtidig med at han kan opretholde en opfattelse af virkeligheden som kontingent og kaotisk. Den første kritik rammer de traditionelle mediers enøjethed:

Massemedierne som omringede Marchen mod Pentagon skabte en skov af unøjagtigheder, der ville stikke blår i øjnene på en historiker; vores roman har givet os muligheden for, nej, instrumentet til at betragte vores fakta og muligvis studere dem i det lys som en gang linsevridning har skabt. 15

Mailers kritik af massemedierne bringer ham i direkte modsætning til Rubin og Hoffman, der surfede på mediernes forvrængninger. Yippierne udnyttede mediernes behov for godt stof til at fremprovokere overskrifter, mens Mailer i Armies of the Night indtager den intellektuelles kritiske position. Den kritiske distance er en fo-rudsætning for den simultane historieskrivning, men det 
er samtidig det punkt, hvor Mailer føler sig afskåret fra den modkultur, den avantgarde han ønsker at tilhøre. Skønt Mailer stiller sig på de unge demonstranters side - Rubins symbolske slag mod systemet, frem for den traditionelle, respektable og næsten småborgerlige ventrefløjs aktivisme - kan han alligevel ikke forlige sig med de unges anti-intellektualisme og historieløshed. Mailer bryder MOBEs pæne facade med sin brovtende fuldskab, men formår samtidig ikke at give slip på rollen som den intellektuelle iagttager (af sig selv). I forordet til Abbie Hoffmans selvbiografi skriver Mailer:

Jeg føler altid at jeg kan tale med autoritet om tresserne, og jeg har aldrig kendt nogen på min alder som ikke havde det på samme måde (prøv på den anden side at finde nogen som får julelys i øjnene når de taler om halvfjerdserne). Men mens jeg læste dette værk, bestemte jeg mig for at min del af tresserne ikke var så stor som jeg troede. Hvis vi skulle sammenli $_{\mathrm{g}} \mathrm{e}$, så levede Abbie dem, jeg observerede dem; Abbie overgav sit liv til dem, mens jeg blot elskede tresserne fordi de gav mit arbejde liv.16

Der var disse to positioner på tressernes venstrefløj. Som eksempel kunne man sammenligne de to mest udadvendte skikkelser i den franske og den amerikanske eksistentialisme, nemlig JeanPaul Sartre og Allen Ginsberg. Begge optrådte som guruer i tresserne og deltog flittigt i demonstrationer. Sartre optrådte som den intellektuelle dogmatiker, der analyserede og holdt taler, mens Ginsberg - buddhisten, fliphovedet - klimprede med fingercymbaler og messede ohmmmmm, for at holde dæmonerne borte og lade de gode vibrationer flyde. Sartre stod for den forbitrede marxisme, der kom til at tegne udviklingen i det europæiske ungdomsoprør og Ginsberg stod for en idealistisk og meget sårbar holisme. Yippierne forlangte en total sammenhæng mellem liv, engagement og kunst og betragtede derfor Mailers kritiske position som småborgerlig og deltidsrevolutionær. Kun ved at glide helt ind i vibrationerne fra Woodstock Nation, kan man være en del af revolutionen:

Maller var forbandet hurtig og allerhelvedes god, selv om han var ved at blive lidt for klinisk og selv om hans sorte tjenestepige åbnede døren. Jo, han var den bedste, den bedste forfatter i deres NATION. I WOOD- 
STOCK NATION er der ingen forfattere - kun digter-krigere.17

Kravet om det totale engagement og den totale autonomi uden for Systemet var yippiernes styrke mens ungdomsoprøret stadig havde et enormt momentum i slutningen af tresserne. Til gengæld var historieløsheden og den anti-intellektualistiske holdningmedvirkende til oprørets bratte forsvinden i begyndelsen af halvfjerdserne, hvor håbløsheden førte til indre splittelse i modkulturen. Stemmerne fra SNCC og The New Left, der i de tidlige tressere kunne samle tusinder i protesten mod de sortes vilkår i Syden eller i en kritik af det amerikanske samfund, druknede i larmen fra en mangfoldighed af politiske og religiøse trosretninger, enkeltsags-bevægelser, kønsdebatter, lokalopgør, terrorisme - for slet ikke at tale om den konstante mumlen fra de mange drop-outs, der gik og 'talte med træerne'. Yippiernes politiske teater var en subversiv kunstart, der legede med Systemets underliggende myter, en decentral og eksperimenterende helhedskunst, der på mange måder minder om fluxus-bevægelsen. Anskuet på denne måde, er der også tydelige forbindelser mellem yippierne og den eksperimenterende litteratur, der netop undergraver læserens forventninger i forhold til kategorier som værk, plot, fiktionslag og sprog. Denne lighed åbner muligvis for et kraftfuldt perspektiv på periodens højlitterære udfoldelser og specielt på firsernes reception. For det første stilles der spørgsmål ved den. postmoderne receptions konstruktion af en apolitisk tresserlitteratur. For det andet trækker yippiernes overfladiske revolutionsromantik tomheden frem i den tænkning, der udbasunerer historiens standsning og referentialitetens endeligt.

Trods overfladiskheden og dyrkelsen af digter-krigerens patos, var yippiernes subversive totalteater en af periodens mest radikale og nyskabende kunstneriske positioner. Skønt yippiernes vej ikke umiddelbart er farbar, kan litteraturhistorien lade sig inspirere af de helhedsaspirationer, der udgår fra stoffet, i stedet for at fastholde kritikkens position udenfor. 
4.

Når Norman Mailers New Journalism idag synes sært bedaget, skyldes det først og fremmest, at hans brud med journalistik, historieskrivning og romankunst blot munder ud i etableringen af et nyt ståsted for en ganske traditionel intellektuel analyse og kritik. Samtidig gælder det, at de fiktive :7irkemidler Mailer benytter er helt traditionelle, fra allegorien og italesættelsen til hans meget bastante brug af metaforer. Hele vejen gennem OfA Fire on the Moon optræder den golde måne således som metafor for WASP kulturens thanatos, mens slagtehuset er metafor for politiets brutalitet over for demonstranterne i Chicagos gader i Miami and the Siege ofChicago og skizofrenien er metafor for USAs mentale landskab i The Annies 'of the Night. Mailers traditionalisme bliver meget tydelig, hvis man holder hans bøger op imod den samtidige udvikling i den eksperimenterende roman, hvor periodens bedste forfattere søgte at overskride genrens begrænsninger indefra i en eksperimenteren med romanens form, virkelighedsreference og politik.

Et glimrende, men sædvanligvis underkendt eksempel er E. L. Doctorows The Book of Daniel fra 1971, der bruger marchen mod Pentagon som det centrale omdrejningspunkt i romanens undersøgelse af historiens betydning, forholdet mellem hændelse og historie og af selve historieskrivningens problem. Ligesom The Armies of the Night skriver The Book of Daniel sig tæt hen over det historiske, tæt hen over faktiske hændelser, mens den søger at fokusere på hvad der reelt skete, snarere end hvad der egentlig skete. Romanen foregår i 1967, hvor hovedpersonen, Daniel Isaacson, sidder på bibliotekssalen på Columbia University og skriver på sin ph.d. afhandling, mens problemer med konen og barnet, søsterens sygdom, erindringer fra barndommen og spørgsmålet om forældrenes skyld, er ved at få ham til at bryde sammen. Daniel Isaacson er søn af et af de mørkeste kapitler i USAs historie.

Daniels forældre er Paul og Rochelle Isaacson, romanens navne for Julius og Ethel Rosenberg, spionerne der udleverede hemmeligheden bag atombomben til Sovjetunionen. Dermed gjorde de sig indirekte skyldige i Koreakrigens udbrud og bragte 
Amerikas og dermed hele verdens fremtid i fare. Det var i hvert fald hvad de blev dødsdømt og siden henrettet for. Rosenbergsagen var den direkte udløber af den første atomprøvesprængning på sovjetisk grund i 1949. Sprængningen sendte chokbølger gennem hele det kommunistforskrækkede amerikanske samfund. Skønt atombomben er en relativt simpel mekanisme, var man fra amerikansk side overbevidst om, at Sovjet kun kunne have trængt ind i 'hemmeligheden' ved spionage. FBI blev sat til at finde en spionring i USA og FBI fandt, som altid, hvad J. Edgar Hoover sagde de skulle. Blandt andet ved hjælp af Gestapos gamle arkiver lykkedes det at skabe en forbindelse fra en tysk atomfysiker i England, over en amerikansk kemiker, til David Greenglass, -der udpegede sin svoger, Julius Rosenberg, som leder af spionringen. I et forsøg på at knække topspionen, blev hans kone Ethel også anklaget, og i 1951 blev de begge dømt til døden på ukonfirmerede forbindelser, fabrikerede beviser og instruerede vidneudsagn. Det vides ikke, om Julius Rosenberg rent faktisk var involveret i spionage, men retssagen var under alle omstændigheder eri farce, og alene derfor var der tale om justitsmord.

I de to år der gik mellem domsafsigelse og henrettelsen i Sing Sings elektriske stol, d. 19. juni 1953, rejste der sig en storm af protester i og uden for USA. Men demonstrationer i USA og i flere vesteuropæiske lande, samt forbønsskrivelser fra tusindvis af mennesker, herunder Jean-Paul Sartre, Albert Einstein og Pave Pius XII, var ikke nok til at fă sagen genoptaget eller dommene omstødt. Ud over den tvivlsomme retsag og dommens hårdhed, rettede mange af protesterne sig mod det faktum, at den amerikanske stat gjorde de to små Rosenberg drenge forældreløse.

Efter forældrenes arrestation var drengene i forskellige former for familiepleje, men da ingen ville kendes ved dem, havnede de på et børnehjem, indtil de blev adopterede af en af forældrenes advokater. I The Book of Daniel kaldes Isaacsons børn Daniel og Susan. Ved romanens start er Susan blevet indlagt på et psykiatrisk hospital efter et selvmordsforsøg. I modsætning til Daniel, der har slugt vreden og skabt sig et liv i anonymiteten under adoptivforældrenes navn, har Susan kæmpet for at rehabilitere 
forældrenes navn ved at oprette en revolutionær fond, der skal støtte aktiviteterne på tressernes nye venstrefløj. Problemet er blot, at skønt the New Left sagtens kan bruge pengene, har den ingen brug for arven fra halvtredserne, ingen brug for historiens martyrer. Daniel prøver at følge Susans krav om at også han skal engagere sig politisk og opsøger Artie Sternlicht, en venstreradikal leder, som romanen har bygget over Jerry Rubin eller Abbie Hoffman. Sternlicht afviser ideen om en Isaacson fond, dels fordi revolutionen allerede vader i martyrer, dels fordi den revolution han arbejder for er et totalt opgør med Historien og Systemet også med det amerikanske kommunistparti, der blot var en spejling af systemet:

Vil du vide hvad der var galt med de gamle amerikanske kommunister? De var inde i systemet. De gik med slips. De havde jobs. De stillede folk op til præsident. The American Communist Party satte venstrefløjen 50 år tilbage. Jeg tror de arbejdede for FBI. Det er den eneste forklaring. De var konspiratoriske. De blev opfundet af J. Edgar Hoover. De var hans største opfindelse.18

Daniel og Susan er tredobbelt eksilerede - på en gang udstødte af det etablerede System-Amerika og fangede mellem det gamle kommunistparti, der slettede-forældrene fra alle medlemslister mindre end et døgn efter at de var blevet arresterede og den nye venstrefløj, der ser forældrene som en del af Systemet, skønt Systemet slog forældrene ihjel. Vreden og det engagement som ingen kan bruge, har knækket Susan, og hun dykker dybere og dybere ned i sindssygen og ind i døden. Hendes død tvinger Daniel til at tage stilling til sit liv - til sit rasende indre eksil, til sin unge kone som han behandler med en grusom og grænseprøv:ende ligegyldighed, og til deres lille dreng - men først og fremmest til Historien.

I mangel af et emne til sin ph.d. afhandling, har Daniel taget fat på selve Historien, men sidder fast i den selvransagende skrivekrampe, der udgør romanen. Daniel flakker mellem første og tredje person ental, mellem vrede og smerte, mellem coolness og sårbarhed, mellem erindringer, nutid, refleksioner og udråb. Hans fortælling er en fragmenteret kalejdoskopi - på en gang et 
ufordøjet sorgarbejde og et bevidst opgør mod den lineære plotstruktur der førte til forældrenes død. Daniel er selv sat sammen af fragmenter fra den amerikanske venstrefløjs historie - et produkt af halvtredserne, der prøver på at vokse op og finde sig selv i tresserne, samtidig med at han både er fanget og nægter at give slip. Spaltningen går igen i Daniels Bog, der har det dobbelte formål at yde forældrene retfærdighed og at bryde ud af arven, der mest af alt minder om en forbandelse. Rochelles sidste ord inden henrettelsen, som Daniel beskriver med smertelig nøjagtighed, var "Let my son be bar mitzvahed today. Let our death be his bar mitzvah."19 Daniel dykker ned i forældrenes historie, tilbage til trediverne, hvor de kom til kommunismen ad forskellige veje moderen Rochelle fordi hun var fattig og faderen Paul gennem en stadig analyseren af uretfærdigheden i det kapitalistiske system - og op til halvtredserne, til retssagen, til henrettelserne af både realisten og idealisten. Paul troede til det sidste, at retfærdigheden og analysen ville redde ham, mens Rochelle vidste at de var udset til at spille en offerrolle og at de kun kunne håbe på at spille den med værdighed.

I et forsøg på at konfrontere sig med en verden udenfor sit eget kogende hoved, tager Daniel til Washington for at være med i marchen mod Pentagon. Han ser Norman Mailer foran Justitsministeriet, afleverer sin militærindkaldelse sammen med hundredevis af andre, marcherer med ud til Pentagon, hvor ingen ved hvad der egentlig skal foregå, men hvor han får muligheden for at se vagterne i øjnene og konfrontere sig med Systemets voldelige magt:

Og pludselig er han der, last arm i arm med nuets virkelige folk, som sidder i et tæt, passivt geled med sammenkædede arme mens støvler nærmer sig, blankpudsede, og køllerne, blankpudsede, og de blankpudsede officerer der vader gennem vores kæde, vores nations mangehjelmede $d_{y}$, som pløjer sig gennem vores kød med støvle og kølle og skydevåben og geværkolbe, gennem vores syge stædighed, gennem vores blod kommer det. Mit land. [. - ]

Daniel drak sit eget blod. Det var Pentagon Saturday Night. Han slugte stumper af sjne tænder. Og han blev løftet ved lemmerne, og han blev arresteret Pentagon Saturday Night.

Og nu vil jeg fortælle dig, hvordan en dreng i den store celle, i dette 
store fællesskab af arresterede brødre, hvordan denne ene dreng er ude af stand til at dele sine kammeraters forslåede muntre fællesskab, eller være interesseret i sladderen om at Artie Sternlicht har overgået alle ved at ende på hospitalet.20

Styrken til at kunne slå sig vej gennem demonstranternes rækker og kroppe repræsenterer den samme magt og det samme System, der slog Daniels forældre ihjel. Mødet med denne rå magtudfoldelse viser Daniel, at Artie Sternlicht undervurderer Systemets styrke og at hans ide om en historieløs revolution, der kun bygger på billeder og følelser, er lige så frugtesløs og naiv som Paul Isaacsons idealisme. De to har flere fællestræk end Sternlicht ved og vil indrømme. Begge er villige til at ofre sig for revolutionen og begge stoler så meget på deres analyser, at analysen hæver sig op over det realistiske. Paul Isaacson så en kraftfuld lighed mellem livet, Historien, teorien og revolutionen, men forstod ikke nuet og blev syndebukken i et nationalt renselsesritual. Artie Sternlicht ser en kraftfuld lighed mellem livet, nuet, kunsten og revolutionen, men afviser Historien og gentager den. Han arver venstrefløjens offerrolle.

Daniel løslades næste dag og finder sin kone hos en ældre dame, der har stillet sit hus til rådighed for de unge demonstranter:

Den næste morgen betalte jeg min bøde og blev løsladt. Det var endnu en vidunderlig dag. Jeg kom tilbage til Washington og fandt min bil og kørte til kvarteret med gamle amerikanske huse og fandt min kone i det stille hvide værelse i det amerikanske hus. Phyllis begyndte straks at græde. Jeg ønskede ikke at hun skulle blive ved og ved. "Hør her", sagde jeg, mens jeg forsøgte at undgå at hvisle mellem tænderne. "Det ser værre ud end det er. Det var der ingen kunst ved. Det er meget lettere at være revolutionær $i$ dag end tidligere."21

5.

The Book of Daniel bringer sin hovedperson frem til tre afslutninger, hvor han kan forlige sig med sin historie: 
Doctorows roman forbinder halvtredsernes og tressernes venstrefløjsradikalisme, i en kritisk historieskrivning, der finder et bindeled mellem den kritiske analyse og formsprogets subversioner af reducerende helhedsperspektiver. The Book of Daniel kan i denne henseende siges at danne bro mellem Mailers og Yippiernes poetikker.

John G. Parks skriver i sin bog om Doctorow at "Daniels bog er ikke en genstand, men et 'liv'; som Whitmans digtni_ng er Daniels kunst kød og blod. 'Den som rører dette, rører et liv', skriver Whitman." 22 Skønt baniel vender sig bort fra Artie Sternlicht, rækker romanen tilbage til Rubin og Hoffmans krav om en kunst, der er revolutionær i sin konkrete gøren. Romanen er på en gang autonom - der er ingen forbindelse mellem Daniel og Doctorow - og uden noget udenfor. Romanen er en poet-warrior, der skriver politikken midt ind i den postmoderne kanon.

Fortælleskematikken i The Book of Daniel betinges indefra af Daniels synsvinkel, hans fragmenterede erindring og hans modstand mod .sekvensen - men udefra ligner den en kommentar til fortællerkonstruktionen i Mailers The Armies of the Night. I begge bøger opstår den sære blanding af en observerende fortæller og en fortalt beskuer, men det tematiske og æstetiske kompleksitetsniveau i The Book of Daniel overflødiggør forfatteren som rigtighedsgarant og politisk vehikel. Doctorows Daniel er mere virkelig end Mailers Mailer. 


\section{Noter}

1. Robert Coover: The Public Burning, New York 1977, s. 399.

2. Hans Hertel, red. Gyldendals Verdenslitteraturhistorie, bind 1, s. 19.

3. ibid., s. 18.

4. Se f.eks. Brian McHales Constructing Postmodernism. New York, 1992; Katherine N. Hayles The Cosmic Web. Ithaca, 1984; Joseph Tabbis The Postmodern Sublime. Ithaca, 1995; Susan Strehles Fiction in the Quantum Universe. Chapel Hill, 1992 eller Tom LeClairs The Art of Excess. Urbana, 1989. Flere af disse bøger forholder sig kritisk til den postmoderne tænkning, men foretrækker alligevel at skabe tematisk bestemte undergenrer, der alene hænger på de valgte værker og som derfor ikke påberåber sig nogen generalitet.

5. Se f.eks. Hans Hauges artikel om John Updike i dette nummer af Passage.

6. John Barth: Lost in the Funhouse. Fiction for print, tape, live voice. New York, 1968. s. 113.

7. Tony Tanner: City of Words: American Fiction 1950-1970. London, 1971.

8. Tanner, s. 18.

9. Se f.eks. "The Port Huron Statement" fra 1962, der blev det samlende manifest for SDS, Students fora Democratic Society, og store dele af The New Left, eller Huey Newton og Bobby Seales Black Panther manifest "What We Want, What We Believe" fra 1966. Begge tekster - og halvanden hundrede andre kilder - findes i Bloom og Breines uundværlige sixties reader: "Takin' it to the stteets", New York, 1995.

10. The Report of the President's Commision on Campus Unrest. New York, 1971 , s. 420.

11. WaltWhitmani "SongofMyself".

12. Jerry Rubin: "How to be a Yippie" i Do It! Scenarios af the Revolution, New York: Simon and Schuster, 1970, s. 82-3. Som eksempel på hvor hurtigt indre splittelser og bifurkationer tog til i tresserbevægelserne, kan det nævnes, at Rubin tog afstand fra denne yippie-myte allerede i sin næste bog, We Are Everywhere, der udkom året efter Do It!. Grunden var ikke, at myten var stivnet, men at han fra så mange sider var blevet gjort opmærksom på at myten er entydigt maskulin og dermed kvindeundertrykkende.

13. Abbie Hoffman Soon to be a Major Motion Picture. New York, 1980, s. 136. How soon is soon? Hoffman begik selvmord i 1989, uden at have set sit liv på film. Men tresserne er over os og lige nu arbejder både Robert Greenwald og Mark Rydell på hvert sit filmprojekt om Abbie Hoffman. 14. Således i Tom Wolfes The Electric Kool-Aid Acid Test, 1968, hvor Wolfe er medrejsende antropolog på Ken Keseys Merry Prankster bus, eller i Hunter S. Thompsons bøger, hvor forfatteren ofte er det eneste bindeled mellem de hovedkuldse analysers enkeltdele.

15. Norman Maller: The Armies af the Night, New York, 1968, s. 219. 
16. Norman Mailer i Abbie Hoffrnan: Soon to be a Major Motion Picture, s. xiv.

17. Abbie Hoffman i essayet : "Landing a Manon the Earth without the help of Norman Mailer". Optrykt i Woodstock Nation. A Talk-Rock Album. New York, 1969, s. 10.

18. E. L. Doctorow The Book af Daniel. London, 1972, side 150. Sternlichts påstand er ikke helt ved siden af. Da der efter J. Edgar Hoovers død i 1972 endelig blev lukket lidt frisk luft ind i FBI, viste det sig, at det amerikanske kommunistparti, der gennem halvtreds år var blevet brugt som skræmmebillede for at øge bevillingerne til FBI, kun talte få tusinde medlemmer, hvoraf en trediedel- herunder det meste af ledelsen - spionerede for FBI.

19. Op.cit., s. 298. Bar rnitzvah er den jødiske konfirmation - en initiering til voksenlivet med dets pligter og ansvar.

20. Op.cit., s. 256.

21. Ibid., s. 257.

22.John G. Parks E.L. Doctorow. New York, 1991, s. 53. For en udfoldet analyse af romanen se envidere Paul Levines glimrende E.L. Doctorow. London 1985.

\section{Bibliografi}

Ud over artiklerne i dette tidsskrift og de i noterne nævnte kilder, har jeg hentet inspiration og pointer fra følgende bøger:

Bradbury, Malcolm. The Modern American Novel. Oxford: Oxford University Press, 1992.

Elliot, Emory, red. The Columbia Literary History af the United States. New York: Columbia University Press, 1988.

-. The Columbia History af the American Novel. New York: Columbia University Press, 1991.

Karl, Frederick R. American Fictions 1940-1980. A Comprehensive History and Critical Evaluation. New York: Harper \& Row, 1983.

Petillon, Pierre-Yves. Histoire de la litterature americaine. Notre demi-siecle 1939-1989. Paris: Fayard, 1992.

Piitz, Manfred. The Story af Identity: American Fiction af the Sixties. Stuttgart: J.B. Metzlersche Verlagsbuchhandlung, 1979.

Ruland, Richard og Malcolm Bradbury. From Puritanism to Postmodernism. A History af American Literature. London: Routledge, 1991. 


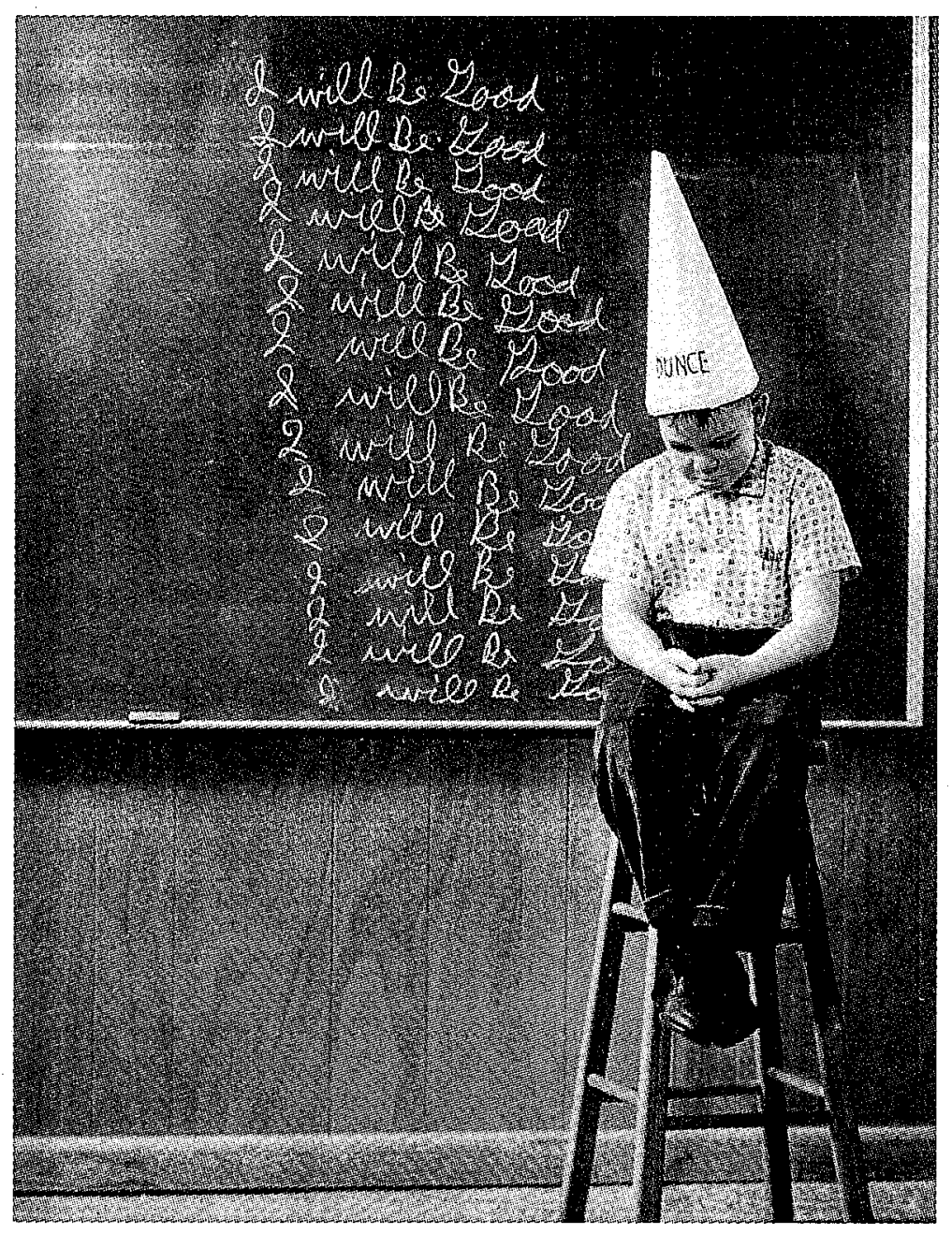

FOCI Image Library 